\title{
Response of microbial decomposition to spin-up explains CMIP5 soil carbon range until 2100
}

\author{
J.-F. Exbrayat ${ }^{1,2}$, A. J. Pitman ${ }^{2}$, and G. Abramowitz ${ }^{2}$ \\ ${ }^{1}$ School of GeoSciences and National Centre for Earth Observation, University of Edinburgh, Edinburgh, UK \\ ${ }^{2}$ ARC Centre of Excellence for Climate System Science and Climate Change Research Centre, \\ University of New South Wales, Sydney, New South Wales, Australia \\ Correspondence to: J.-F. Exbrayat (j.exbrayat@ed.ac.uk)
}

Received: 2 May 2014 - Published in Geosci. Model Dev. Discuss.: 21 May 2014

Revised: 29 September 2014 - Accepted: 8 October 2014 - Published: 13 November 2014

\begin{abstract}
Soil carbon storage simulated by the Coupled Model Intercomparison Project (CMIP5) models varies 6fold for the present day. Here, we confirm earlier work showing that this range already exists at the beginning of the CMIP5 historical simulations. We additionally show that this range is largely determined by the response of microbial decomposition during each model's spin-up procedure from initialization to equilibration. The 6-fold range in soil carbon, once established prior to the beginning of the historical period (and prior to the beginning of a CMIP5 simulation), is then maintained through the present and to 2100 almost unchanged even under a strong business-as-usual emissions scenario. We therefore highlight that a commonly ignored part of CMIP5 analyses - the land surface state achieved through the spin-up procedure - can be important for determining future carbon storage and land surface fluxes. We identify the need to better constrain the outcome of the spinup procedure as an important step in reducing uncertainty in both projected soil carbon and land surface fluxes in CMIP5 transient simulations.
\end{abstract}

\section{Introduction}

The land surface currently absorbs about a third of anthropogenic emissions of $\mathrm{CO}_{2}$ (Canadell et al., 2007; Le Quéré et al., 2009) and so helps to offset global warming. Future global warming may enhance microbial decomposition and emissions of $\mathrm{CO}_{2}$ from respired soil organic carbon (SOC), the largest carbon pool in the terrestrial biosphere (Jobbágy and Jackson, 2000). Higher emissions from
SOC could accelerate increases in atmospheric $\mathrm{CO}_{2}$ concentrations even if plant carbon uptake by photosynthesis increased under higher atmospheric $\mathrm{CO}_{2}$ (Ahlström et al., 2013; Friedlingstein et al., 2014; Nishina et al., 2014). Conversely, if the soil remains a carbon sink (Le Quéré et al., 2009; Lund et al., 2010) the negative feedback on rising atmospheric $\mathrm{CO}_{2}$ (Davidson and Janssens, 2006) would help limit rates of increase. How soil carbon is represented in models and how it responds to climate is critical to resolving whether the land will remain a sink or become a source of $\mathrm{CO}_{2}$.

Recent model intercomparisons, such as the fifth phase of the Coupled Model Intercomparison Project (CMIP5; Taylor et al., 2012) and the Inter-Sectoral Impact Model Intercomparison Project (ISI-MIP; Warszawski et al., 2014), have highlighted a lack of consensus among models on whether the soil carbon sink will be sustained during the 21st century (Friedlingstein et al., 2014; Nishina et al., 2014). These models also exhibit large discrepancies in stores of SOC they simulate. For example, Todd-Brown et al. (2013) report that total SOC simulated by CMIP5 models for the present day represents a 6-fold variation ranging from $\sim 510$ to $\sim 3040 \mathrm{Pg} \mathrm{C}$. Another large range $(\sim 1090$ to $\sim 2645 \mathrm{Pg} \mathrm{C})$ exists in the present day SOC simulated by ISI-MIP models despite being driven by a harmonized weather data set (Nishina et al., 2014). These latter results indicate that a significant fraction of the uncertainty in estimates of total SOC arises from the representation of land processes rather than differences in climate drivers. 
Soil carbon pools of widely different sizes have the potential to react differently to future climate change. We therefore examine the likely reasons for the large differences between CMIP5 models in their simulation of SOC. This work is founded in the recognition that the SOC varies among the CMIP5 models for the present day over a 6-fold range (ToddBrown et al., 2013) and this range contributes to model-tomodel variations in SOC change in the future (Todd-Brown et al., 2014). We explore why this 6-fold range exists and ultimately show that individual model responses to the spinup procedure, particularly the dominant role of turnover time relative to SOC input, are the key reason for this range. Explaining why the amount of carbon mobilized in the active cycle varies greatly between models is critical but has been largely ignored in the literature to date. As noted by Knutti and Sedláček (2013), there may be multiple sources of disagreement between models such as a lack of process understanding, or the reduced availability of relevant observational data sets to constrain models. Technical aspects of climate modelling, such as how different state variables are initialized or spun up to an equilibrated state prior to an experiment being conducted, and how equilibration is defined in this context, can also lead to major differences between model simulations. Discriminating between these sources of uncertainty to understand why CMIP5 models differ so significantly in the amount of SOC in the present day, and subsequently in the total amount of $\mathrm{C}$ mobilized in the global cycle under a future climate, enables an improvement in model projections. Increasing the consistency between models is required to improve our confidence in the sign of the soil carbon feedback in the future.

To avoid misconceptions, we define and differentiate between two states that are commonly called "initial" states in land modelling. Our definition of "initial state", which is not known or reported in CMIP5 models, is the state at the beginning of a climate model integration. This "initial state" may come from a previous simulation, from off-line simulations, from observations or via expert judgement. In the case of SOC, it may be initialized as a "cold start" or in a state equilibrated with an atmosphere that reflects the period prior to the beginning of a simulation. This model state is then commonly integrated forward in time until those model states that are considered important are in equilibrium with the atmospheric model over some period of time and to a degree that is defined by the modeller (but not reported). This generates what we define as an "equilibrated state". In CMIP5, simulations are then reported from the beginning of the historical period (say 1850), initialized with this "equilibrated state" and integrated forward in time to the present day under observed forcings, and then into the future using a representative concentration pathway (Taylor et al., 2012). The values of a climate model's state variables at 1850 are commonly thought of as the "initial state" but they are not; it is the model-specific equilibrated state under pre-industrial forcing and this reflects the ability of the climate model to represent global and regional temperatures, rainfall and so forth. We therefore call this the "equilibrated state" and note that this differs from the "initial state" due to the earth system model's simulated climate, the definition of "equilibrium" over time and space and crucially how the state variables are parameterized. Here we show that a great deal of the 6-fold range in SOC in the CMIP5 models at the "equilibrated state" assumed representative of 1850 (and consequently in the present day reported by Todd-Brown et al., 2013) is a consequence of the procedures used to evolve the model from the "initial state" to the "equilibrated state". These procedures may influence how SOC changes through to 2100 (Todd-Brown et al., 2014) due to the current stateof-the-art representation of SOC decomposition.

\section{Material and methods}

\subsection{SOC in earth system models}

In all global terrestrial models participating in recent intercomparison projects such as CMIP5 and ISI-MIP, the SOC balance and its change $(\triangle \mathrm{SOC})$ are represented in a similar way. First, inputs of carbon into the soil are derived from plant pools. Plant carbon uptake and turnover times respond to climate change, climate variability and atmospheric $\mathrm{CO}_{2}$ independent of the size of the SOC pools. Meanwhile, modelled microbial decomposition releases carbon by heterotrophic respiration $\left(R_{\mathrm{h}}\right)$. The balance can be summarized by

$\Delta \mathrm{SOC}=\mathrm{SOC}_{\mathrm{in}}-R_{\mathrm{h}}$,

where $\mathrm{SOC}_{\text {in }}$ is the input to the SOC pools from plant and litter pools.

Microbial decomposition is commonly represented as a first-order process and applied to a succession of pools. In each pool, a parameter $k$ reflects the specific baseline decomposition rate (Xia et al., 2013; Exbrayat et al., 2013a, b) at a reference soil temperature and non-limiting moisture conditions. Then, the decay rate is adjusted at each time step by an environmental scalar (Todd-Brown et al., 2013; Xia et al., 2013; Exbrayat et al., 2013a, b; Nishina et al., 2014) that describes the instantaneous response of microbial activity to the soil physical state as the product of a soil temperature $\left(f_{T}\right)$ and a soil moisture respiration function $\left(f_{W}\right)$. Various formulations of $f_{T}$ and $f_{W}$ have been implemented in model codes (Lloyd and Taylor, 1994; Falloon et al., 2011; Todd-Brown et al., 2013; Exbrayat et al., 2013a, b; Nishina et al., 2014), usually assuming a space- and time-invariant response to the same conditions. Their effect on decay rate varies according to local soil conditions and therefore climate.

The actual decay rate $\left(k \times f_{T} \times f_{W}\right)$ is applied to the amount of substrate available, SOC, to determine the amount of microbial decomposition $D_{\mathrm{m}}$ at each model time step:

$D_{\mathrm{m}}=k \times f_{T} \times f_{W} \times \mathrm{SOC}$, 
Table 1. CMIP5 models and number of simulations used in this paper for historical and RCP 8.5 runs. The first column provides the letter code used in the figures. References and details about soil carbon components are provided in Table 2.

\begin{tabular}{|c|c|c|c|c|}
\hline & \multirow[b]{2}{*}{ Model name } & \multirow[b]{2}{*}{ Institution } & \multicolumn{2}{|c|}{ Number of model runs } \\
\hline & & & Historical & RCP 8.5 \\
\hline A & BCC-CSM1.1 & Beijing Climate Center (China) & 3 & 0 \\
\hline B & CanESM2 & Canadian Centre for Climate Modelling and Analysis (Canada) & 5 & 5 \\
\hline $\mathrm{C}$ & CCSM4 & National Center for Atmospheric Research (USA) & 6 & 6 \\
\hline $\mathrm{D}$ & GFDL-ESM2G & Geophysical Fluid Dynamics Laboratory (USA) & 1 & 1 \\
\hline \multirow[t]{2}{*}{$\mathrm{E}^{*}$} & GISS-E2-H & NASA Goddard Institute for Space Studies (USA) & 17 & 3 \\
\hline & GISS-E2-R & & 25 & 3 \\
\hline \multirow[t]{2}{*}{$\mathrm{F}^{*}$} & HadGEM2-CC & Met Office/Hadley Centre (UK) & 1 & 1 \\
\hline & HadGEM2-ES & & 3 & 3 \\
\hline \multirow[t]{2}{*}{$\mathrm{G}^{*}$} & IPSL-CM5A-LR & Institut Pierre Simon Laplace (France) & 6 & 4 \\
\hline & IPSL-CM5B-LR & & 1 & 1 \\
\hline \multirow[t]{2}{*}{$\mathrm{H}^{*}$} & MIROC-ESM & Japan Agency for Marine-Earth Science and Technology (Japan) & 3 & 1 \\
\hline & MIROC-ESM-CHEM & & 1 & 1 \\
\hline I & MPI-ESM-LR & Max Planck Institute (Germany) & 3 & 3 \\
\hline \multirow[t]{2}{*}{$\mathrm{J}^{*}$} & NorESM1-M & Bjerknes Centre for Climate Research (Norway) & 3 & 1 \\
\hline & NorESM1-ME & & 1 & 1 \\
\hline
\end{tabular}

* Models from the same institution were averaged to avoid pseudo-replication.

where $k \times f_{T} \times f_{W}$ is equivalent to the fraction of respired substrate, the inverse of the turnover time $\mathrm{SOC} / R_{\mathrm{h}}$. A part of the decomposed organic matter is routed to pools with longer turnover time and the rest is emitted as $\mathrm{CO}_{2}$. There may be variations between models in the number of pools they represent (Todd-Brown et al., 2013; Nishina et al., 2014) and the formulations of the environmental response functions (Falloon et al., 2011; Exbrayat et al., 2013a) but at the ecosystem scale, $R_{\mathrm{h}}$ is proportional to the amount of substrate, i.e. SOC, available in the soil. This parameterization may be inconsistent with our current understanding of microbial decomposition (Allison et al., 2010; Schmidt et al., 2011; Wieder et al., 2013) because it lacks the representation of processes such as microbial activity and priming effect (e.g. Xenakis and Williams, 2014). However, the first-order dependency of $R_{\mathrm{h}}$ on SOC, soil temperature and moisture is able to explain complex phenomena such as the apparent acclimation of decomposers to warming by quick depletion of the most labile substrate pools (Luo et al., 2001; Kirschbaum, 2004; Knorr et al., 2005).

\subsection{CMIP5 data}

From the CMIP5 archive we downloaded monthly soil carbon density ( $c$ Soil in metadata), litter carbon density ( $c$ Litter) and heterotrophic respiration $(r h)$ for 15 CMIP5 models from 10 international institutions. A list of models can be found in Table 1 while further details about models and land components have been summarized in Table 2 . We note that four of these models, namely BCC-CSM1.1 (model A), CCSM4 (model C), NorESM1-M and NorESM1ME (grouped as model $\mathrm{J}$ ), represent nitrogen limitation on plant productivity while the others do not. We selected data for the historical (1850-2005) and the most intensive Representative Concentration Pathway 8.5 (RCP 8.5, 2006-2100) experiments. A total of 79 simulations for the historical experiment, including 34 simulations continuing for RCP 8.5 (Table 1) were available. When cLitter was reported, we added it to $c$ Soil as both pools are parameterized to generate $R_{\mathrm{h}}$ following first-order kinetics.

To calculate stock sizes we first multiplied spatially explicit data of $c$ Soil and cLitter in $\mathrm{kg} \mathrm{C} \mathrm{m}^{-2}$ by corresponding grid-cell areas (areacella in metadata) and integrated their values globally. Similarly, we calculated global fluxes of $R_{\mathrm{h}}$ by multiplying monthly fluxes in $\mathrm{kg} \mathrm{C} \mathrm{m}^{-2}$ by grid-cell areas and integrating them globally. Fluxes were summed to obtain annual averages. Annual soil carbon input $\left(\mathrm{SOC}_{\mathrm{in}}\right)$ from above-ground biomass was not available from the database. Therefore, we calculated it by inverting the SOC balance:

$\mathrm{SOC}_{\mathrm{in}}=\Delta \mathrm{SOC}+R_{\mathrm{h}}$.

As models did not start their historical simulations at the same time, we focus our analyses on the overlapping period of 1861-2100. We also averaged all simulations from the same model or institution in an attempt to account for model dependence (see Bishop and Abramowitz, 2013, for a discussion on the topic).

In the following, we report values of stocks and fluxes averaged for three periods of time, the pre-industrial (1861-1870), modern (1996-2005) and future (2091-2100) periods. While the period $1861-1870$ is not part of the preindustrial control runs sensu stricto, the minor increase in atmospheric $\mathrm{CO}_{2}$ between pre-industrial times (i.e. before 1850) and 1870 is unlikely to have led models to simulate 
Table 2. Details about the CMIP5 models' terrestrial and soil components and associated references.

\begin{tabular}{|c|c|c|c|c|c|c|}
\hline & \multirow[b]{2}{*}{ Model name } & \multirow[b]{2}{*}{ Terrestrial component } & \multirow[b]{2}{*}{ Soil biogeochemistry } & \multicolumn{2}{|c|}{ \# of pools } & \multirow{2}{*}{$\begin{array}{c}\mathrm{N} \\
\text { limitations }\end{array}$} \\
\hline & & & & $\mathrm{L}$ & $\mathrm{S}$ & \\
\hline A & BCC-CSM1.1 (Wu et al., 2013) & AVIM2 (Ji et al., 2008) & Based on CENTURY (Parton et al., 1987) & 2 & 6 & No \\
\hline $\mathrm{B}$ & CanESM2 (Chylek et al., 2011) & CTEM (Arora and Boer, 2010) & CTEM (Arora and Boer, 2010) & 1 & 1 & No \\
\hline $\mathrm{C}$ & CCSM4 (Gent et al., 2011) & CLM4-CN (Lawrence et al., 2011) & $\begin{array}{l}\text { CN module (Thornton et al., 2007) based on } \\
\text { Biome-BGC } 4.1 .2 \text { (Thornton and Rosenbloom, } \\
\text { 2005) }\end{array}$ & 3 & 3 & Yes \\
\hline $\mathrm{D}$ & GFDL-ESM2G (Dunne et al., 2012) & LM3.0 (Shevliakova et al., 2009) & Based on CENTURY (Parton et al., 1987) & - & 2 & No \\
\hline $\mathrm{E}$ & GISS-E2 (Shindell et al., 2013) & NCAR-CSM1.4 (Doney et al., 2006) & Based on CASA (Randerson et al., 1997) & - & 9 & No \\
\hline $\mathrm{F}$ & HadGEM2 (Collins et al., 2011) & JULES (Clark et al., 2011) & $\begin{array}{l}\text { Based on TRIFFID (Cox, 2001) and RothC } \\
\text { (Jenkinson, 1990) }\end{array}$ & - & 4 & No \\
\hline G & IPSL-CM5 (Dufresne et al., 2013) & ORCHIDEE & $\begin{array}{l}\text { STOMATE (Krinner et al., 2005) and } \\
\text { CENTURY (Parton et al., 1988) }\end{array}$ & 3 & 4 & No \\
\hline $\mathrm{H}$ & MIROC-ESM (Watanabe et al., 2011) & SEIB-DGVM (Sato et al., 2007) & Based on DEMETER-1 (Foley, 1995) & - & 2 & No \\
\hline I & MPI-ESM-LR (Giorgetta et al., 2013) & JSBACH (Raddatz et al., 2007) & $\begin{array}{l}\text { Based on Bethy (Knorr, 2000) and CENTURY } \\
\text { (Parton et al., 1988) }\end{array}$ & 1 & 1 & No \\
\hline $\mathrm{J}$ & NorESM1 (Bentsen et al., 2013) & CLM4-CN (Lawrence et al., 2011) & $\begin{array}{l}\text { CN module (Thornton et al., 2007) based on } \\
\text { Biome-BGC } 4.1 .2 \text { (Thornton and Rosenbloom, } \\
\text { 2005) }\end{array}$ & 3 & 3 & Yes \\
\hline
\end{tabular}

a strong change in the greenhouse effect and terrestrial $\mathrm{C}$ fluxes. Values are shown in Table 3.

\subsection{Harmonized world soil database}

HWSD (FAO, 2012) is a global data set of dominant soil units at a $30 \mathrm{~s}$ arc resolution, providing soil properties for the top $(0-30 \mathrm{~cm})$ and sub-soil $(30-100 \mathrm{~cm})$. We use version 1.21 and follow the approach by Todd-Brown et al. (2013) to obtain global values. First, we regrid the HWSD by selecting dominant soil units in a $0.5^{\circ}$ latitude $\times 0.5^{\circ}$ longitude grid. Then, we multiply the organic carbon content of the dominant soil units (in \% weight) by the bulk density (provided in $\mathrm{kg} \mathrm{dm}^{-3}$ ) to obtain the carbon density (in $\mathrm{kg} \mathrm{Cm}^{-2}$ ) in each $0.5^{\circ} \times 0.5^{\circ}$ grid cell. We multiply the density by the surface area of each grid cell and sum results to obtain a total soil carbon content of $\sim 1170 \mathrm{Pg} \mathrm{C}$. Following Todd-Brown et al. (2013), a confidence interval of $29 \%$ below the mean (i.e. $\sim 830 \mathrm{Pg} \mathrm{C}$ ) to $32 \%$ above the mean (i.e. $\sim 1550 \mathrm{Pg} \mathrm{C}$ ) was considered to take variations in soil carbon content and the mapping processes into account. The range we obtain is slightly smaller than reported by Todd-Brown et al. (2013) $(890-1660 \mathrm{PgC}$ ) because we use an updated version of the HWSD and did not replace bulk density values for Andisols and Histosols.

\section{Results}

We first compare total SOC for pre-industrial (1861-1870), modern (1996-2005) and future (2091-2100) periods. Figure 1 compares the total SOC range in CMIP5 models for 1861-1870 (563-2938 Pg C), 1996-2005 (576-3047 Pg C), and 2091-2100 (582-3266 Pg C, derived using the RCP 8.5 scenario). All three periods show very similar distributions of SOC among the models and the present day and future ranges already exist at the beginning of the historical simulations. Figure 1 highlights that the size of SOC pools of individual CMIP5 models remains largely consistent over the three time periods. Indeed, pre-industrial SOC predicts modern SOC, modern SOC predicts future SOC and pre-industrial SOC predicts future stocks with a high degree of precision (Fig. 1). Also represented in Fig. 1 is the $95 \%$ confidence interval of total SOC estimated from HWSD that we use as a reference for modern total SOC (i.e. in 1996-2005). We note that only three models fall within this range: BCC-CSM1.1 (model A), CanESM2 (model B) and HadGEM2 (model F). Models based on the CLM4 land surface model (i.e. models $\mathrm{C}$ and $\mathrm{J}$ ) underestimate modern SOC while all remaining models overestimate it. Note that these models $\mathrm{C}$ and $\mathrm{J}$ include nitrogen limitation of the vegetation response to increasing $\mathrm{CO}_{2}$.

We next investigate the likely reasons for the existence of this pre-industrial CMIP5 range in total SOC. The first obvious step is to check whether models are at equilibrium prior to climate change experiments. Models may not agree on total SOC simply because some of them, and especially those at the extremes of the CMIP5 spectrum, are still drifting towards their own steady-state and therefore do not comply with our experiment protocol. In Fig. 2 we show the relationship between pre-industrial $\mathrm{SOC}_{\mathrm{in}}$ and $R_{\mathrm{h}}$. This relationship is highly significant $\left(R^{2}=1 ; p<0.001\right)$ and strongly suggests that all models were equilibrated under pre-industrial boundary conditions. This removes the possibility that models were not in equilibrium and means that the 6-fold CMIP5 range is likely linked with the internal terrestrial processes represented in these models.

Two major internal terrestrial processes are involved: $\mathrm{SOC}_{\mathrm{in}}$, the amount of SOC that enters the soil pools, and the turnover time of organic matter that corresponds to the amount of SOC that is released from soil pools. The 
Table 3. Model specific values of $\mathrm{SOC}_{\mathrm{in}}, R_{\mathrm{h}}$ and SOC used in Figs. 1 to 4 . Values are averaged over the indicated years. All data are rounded to whole numbers. Values for 2091-2100 are from the Representative Concentration Pathway 8.5 (RCP 8.5) simulations.

\begin{tabular}{|c|c|c|c|c|c|c|c|c|c|}
\hline \multirow[b]{2}{*}{ Model } & \multicolumn{3}{|c|}{ 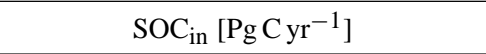 } & \multicolumn{3}{|c|}{$R_{\mathrm{h}}\left[\mathrm{Pg} \mathrm{C} \mathrm{yr}^{-1}\right]$} & \multicolumn{3}{|c|}{ Total soil carbon $[\mathrm{Pg} \mathrm{C}]$} \\
\hline & $1861-1870$ & 1996-2005 & $2091-2100$ & $1861-1870$ & 1996-2005 & 2091-2100 & $1861-1870$ & 1996-2005 & $2091-2100$ \\
\hline A & 75 & 87 & - & 75 & 86 & - & 1273 & 1351 & - \\
\hline B & 57 & 64 & 84 & 56 & 65 & 85 & 1511 & 1541 & 1490 \\
\hline C & 46 & 49 & 56 & 46 & 49 & 57 & 563 & 576 & 582 \\
\hline $\mathrm{D}$ & 79 & 85 & 119 & 79 & 86 & 120 & 1798 & 1781 & 1785 \\
\hline $\mathrm{E}$ & 45 & 55 & 58 & 45 & 55 & 61 & 2113 & 2306 & 2118 \\
\hline $\mathrm{F}$ & 67 & 86 & 140 & 67 & 84 & 137 & 1178 & 1287 & 1596 \\
\hline G & 76 & 87 & 123 & 76 & 87 & 123 & 1598 & 1626 & 1709 \\
\hline $\mathrm{H}$ & 57 & 59 & 71 & 56 & 55 & 74 & 2515 & 2566 & 2494 \\
\hline I & 66 & 75 & 100 & 66 & 74 & 99 & 2938 & 3047 & 3266 \\
\hline $\mathrm{J}$ & 52 & 55 & 61 & 52 & 55 & 62 & 650 & 666 & 654 \\
\hline
\end{tabular}

relationship between $\mathrm{SOC}_{\mathrm{in}}$ and total $\mathrm{SOC}$ during the preindustrial period is shown in Fig. 3. Overall, the relationship is not significant $\left(R^{2}=0.04 ; p=0.604\right)$. Further, the models that equilibrate with the largest total SOC stock (models E, H, I) are not the models with the largest SOC input. Similarly, the small equilibrated SOC pool size of models C and $\mathbf{J}$ seems unrelated to $\mathrm{SOC}_{\text {in }}$ despite these models including $\mathrm{N}$ limitations on plant productivity and $\mathrm{SOC}_{\mathrm{in}}$. In short, the amount of $\mathrm{SOC}_{\mathrm{in}}$ cannot explain the size of the equilibrated pools. In Fig. 4, we therefore present the relationship between the pre-industrial SOC turnover time (i.e. the inverse of the decay rate expressed as SOC $\left./ R_{\mathrm{h}}\right)$ and total SOC. This relationship is highly significant $(p<0.001)$ and linear $\left(R^{2}=0.84\right)$ and models with a longer turnover time, i.e. a low decay rate, require larger pools to offset the same SOC input, and vice versa. Further, turnover times are not affected by the number of SOC pools represented. Models with the longest turnover time have alternatively nine (model E) or two pools (models $\mathrm{H}$ and I), while models with the shortest turnover time have eight (model A), six (models $\mathrm{C}$ and $\mathrm{J}$ ) or four pools (model F).

\section{Discussion}

Despite the change imposed on boundary conditions during global warming experiments (Anav et al., 2013; Friedlingstein et al., 2014), CMIP5 present day and projected SOC stocks are largely determined by their equilibrated pool size (Fig. 1) in 1860. This was not unexpected due to the slow response of SOC pools but it clearly shows that modern and future stocks are mostly defined by the equilibrated pool size while changes can be explained by a combination of changes in the input and output fluxes (see Todd-Brown et al., 2014, for a detailed account of these mechanisms). Further, as SOC in 1860 is unknown from observations, CMIP5 models use a spin-up procedure from an initial state assuming steady preindustrial boundary conditions (Xia et al., 2012) to obtain an equilibrated state for pre-industrial SOC. In order to reach equilibrium, iterative or semi-analytical methods (e.g. Xia et al., 2012) are employed to reach the pool sizes required to balance input $\left(\mathrm{SOC}_{\mathrm{in}}\right)$ and output fluxes $\left(R_{\mathrm{h}}\right)$. Steady-state is assumed when the trend in $\triangle \mathrm{SOC}$ becomes negligible. Hence, it is not the actual value of SOC that defines the equilibrium but its lack of variation in time (Xia et al., 2013; Exbrayat et al., 2013b). It is worrisome that these procedures are not clearly documented and therefore how a model is evolved from its true "initial state" to its "equilibrated state" is not known.

However, we have verified that all CMIP5 models were close to equilibrium prior to the initiation of climate change experiments. Following Eqs. (1) and (2), the model-specific value of SOC obtained by a model via spin-up depends on two factors. First, if $\mathrm{SOC}_{\text {in }}$ is large, a larger SOC pool is required to offset it through microbial decomposition and $R_{\mathrm{h}}$, for a given decay rate, $k \times f_{T} \times f_{W}$. Conversely, low values of $S C_{i n}$ lead SOC pools to equilibrate to lower values for a particular decay rate. Second, if the decay rate is high (short turnover time) during spin-up, SOC pools will remain small, for a given $\mathrm{SOC}_{\mathrm{in}}$. Conversely, low decay rates, or long turnover time, will require large pools of substrate to offset the same input $\mathrm{SOC}_{\mathrm{in}}$. Both factors are modelspecific: $\mathrm{SOC}_{\mathrm{in}}$ is derived from plant primary productivity fluxes (Davidson and Janssens, 2006) while the baseline decomposition rate $k$ and the shape of the response functions $f_{T}$ and $f_{W}$ are highly model-dependent (Falloon et al., 2011; Exbrayat et al., 2013a, b; Todd-Brown et al., 2013).

Here we have shown that the large range exhibited by CMIP5 SOC is principally due to the response of microbial decomposition during the spin-up process. This is a long process that corresponds to multiple centuries of steady climate conditions but as noted is not reported as part of CMIP5 and might represent a short period if the "initial state" is already well equilibrated or may represent many centuries if not. Throughout this period, however, for each CMIP5 model, model-specific parameter $k$ and environmentalresponse functions $f_{T}$ and $f_{W}$ drive SOC pools to the size required by the 

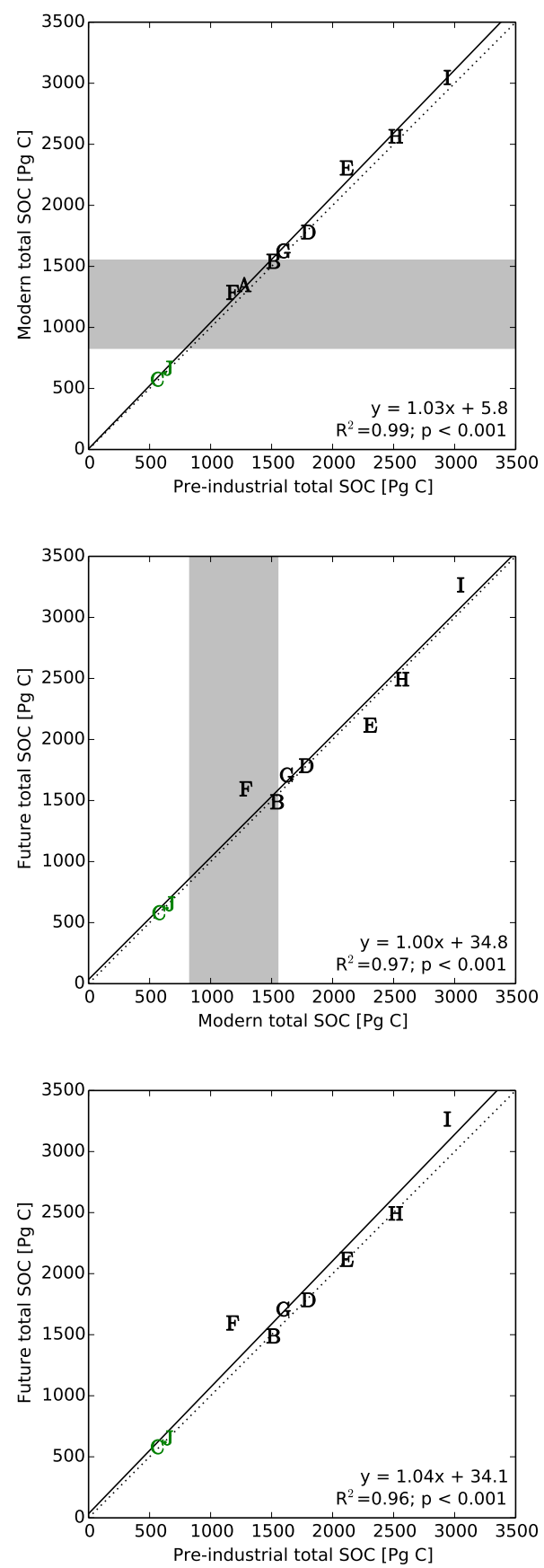

Figure 1. Relationship between total SOC in CMIP5 models at two different times: modern stocks as a function of pre-industrial stocks (upper panel), future stocks as a function of modern stocks (middle panel) and future stocks as a function of pre-industrial stocks (lower panel). Letters correspond to models as in Table 1 and models in green (i.e. $\mathrm{C}$ and $\mathrm{J}$ ) integrate nitrogen limitation. The grey area is the $95 \%$ confidence interval of modern total SOC derived from the HWSD. Equation, $R^{2}$ and $p$ values correspond to the linear relationship between stocks built using data from all models (solid line). The dotted line is the $1: 1$ line.

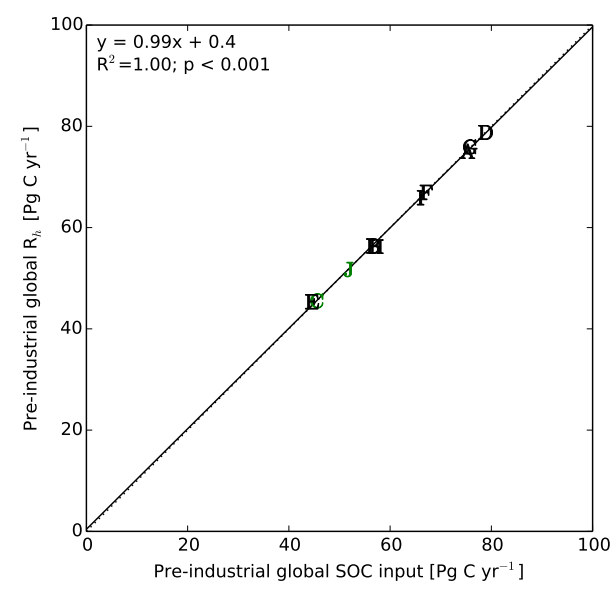

Figure 2. Relationship between pre-industrial global SOC input and pre-industrial $R_{\mathrm{h}}$. Letters are the same as in Table 1 and models in green (i.e. $\mathrm{C}$ and $\mathrm{J}$ ) integrate nitrogen limitation. The solid line is a linear relationship constructed using all models with equation, $R^{2}$ and $p$ values indicated in the top left corner. The dotted line represents the $1: 1$ relationship.

turnover time they simulate to compensate for $\mathrm{SOC}_{\mathrm{in}}$. This observation corroborates the predominance of turnover time in the uncertainty of ecosystem response to climate change (Friend et al., 2014) and Fig. 4 shows that it is independent of the number of pools considered in each model. The resulting equilibrated state obtained prior to the initiation of CMIP5 transient simulations propagates through the present and into the future even when one is using RCP 8.5.

Our results raise a critical problem linked to model initialization and then equilibration by spin-up. According to our analysis of the CMIP5 models, a simple solution to reduce the uncertainty in simulated SOC stocks would be to modify model parameters, especially those related to SOC turnover, to obtain a steady-state consistent from model to model with SOC values representative of pre-industrial conditions. Alternatively, because of the millennial timescales of soil genesis, as well as land use changes, steady-state of global SOC stocks is not guaranteed to have existed at the end of the preindustrial era. Therefore, one could choose to consider only model parameters that achieve modern stocks in accordance with observations in response to past changes (e.g. Exbrayat et al., 2014). However, this would require multiple realizations of computationally expensive models, or the use of emulators. Furthermore, it would be necessary to represent site history, and especially disturbances, with a high degree of confidence during simulations to avoid over-fitting parameters and this may not be realistic at global scale. Therefore, assuming an equilibrated pre-industrial state is a more readily available option that is supported by the lack of variations in simulated SOC during historical experiments despite changing boundary conditions. 


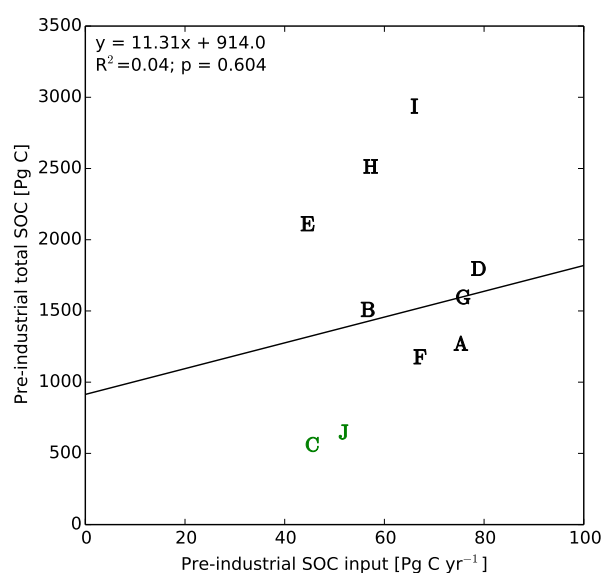

Figure 3. Relationship between pre-industrial SOC input and preindustrial total SOC stocks at the beginning of the historical experiment. Letters correspond to the same models as in Table 1 and models in green (i.e. $\mathrm{C}$ and $\mathrm{J}$ ) integrate nitrogen limitation. The solid line is a linear relationship constructed using all models with equation, $R^{2}$ and $p$ values indicated in the top left corner.

Thus, we suggest that one could use available estimates and confidence interval of modern SOC stocks to constrain the pre-industrial equilibrated state. These estimates include global data sets such as HWSD and other (Shangguan et al., 2014) but also regional data that may better represent high latitude stocks and permafrost (e.g. Northern Circumpolar Soil Carbon Database; Hugelius et al., 2013). Of course, while changing parameter values corresponding to SOC turnover time is relatively straightforward, it would be important to ensure that these pools are sustained by an input representative of carbon uptake. At equilibrium $\mathrm{SOC}_{\text {in }}$ equals net primary productivity (NPP) because plant pools do not vary in size. Here all models predict $\mathrm{SOC}_{\text {in }}$ within two standard deviations of the uncertainty range of modern, high confidence, NPP estimates (56.4 $\pm 8-9 \mathrm{Pg} \mathrm{C} \mathrm{yr}^{-1}$; Ito, 2011). Although not directly comparable with pre-industrial values, this global estimate indicates that models simulate acceptable values of global carbon uptake.

As decomposition processes are represented following first-order kinetics, simulating more realistic SOC stocks from an initial condition, and through spin-up to an equilibrated state in response to adequate uptake fluxes would likely lead models to represent more correct modern stocks. Nevertheless, as each model relies on its own formulation of the response functions $f_{T}$ and $f_{W}$, the ensemble would still exhibit different sensitivities of SOC stocks to climate change. However, by removing a degree of freedom associated with spin-up procedures, we believe that these observational data sets are a valuable tool for increasing the consistency between models and making them more comparable. It would improve the confidence we can have in projections of SOC fluxes and feedbacks on future climate change.

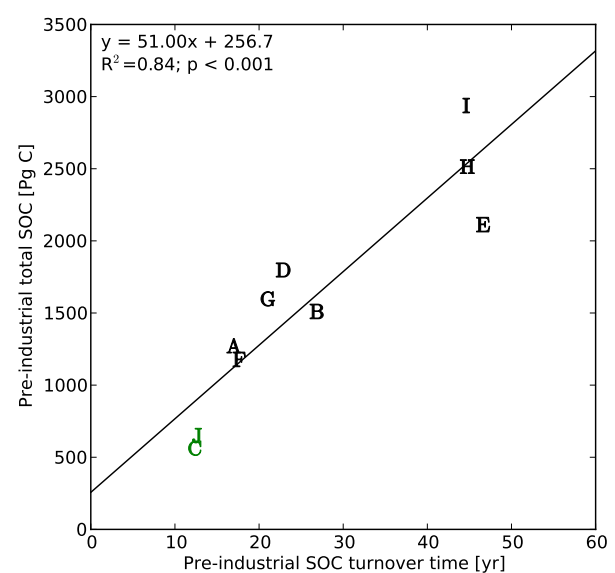

Figure 4. Relationship between pre-industrial global SOC turnover time and total SOC. Letters correspond to the same models as in Table 1 and models in green (i.e. $\mathrm{C}$ and $\mathrm{J}$ ) integrate nitrogen limitation. The solid line is a linear relationship constructed using all models with equation, $R^{2}$ and $p$ values indicated in the top left corner.

\section{Conclusions}

We have demonstrated that the 6-fold range in SOC stocks simulated by CMIP5 models can be explained by the modelspecific response of microbial decomposition to spin-up under pre-industrial conditions. Model-dependent parameter and response functions drive the size of the pools to the amount required by decay rates to offset $\mathrm{SOC}_{\text {in }}$ under the steady-state assumption. Once established, the resulting pool sizes remain similar through to the present and into the future even under the high-emission RCP8.5 scenario that generates future conditions the least similar to current ones. We therefore identify the spin-up procedure, and especially the response of microbial decomposition during this very long model integration, as a key source of uncertainty in the simulation of SOC in CMIP5 models. Critically, this involves the interaction of a technical and a process-linked uncertainty in CMIP5 models' experimental framework. The technical methods used for spin-up are model specific and not commonly reported. Interlinked with the technical uncertainty is the parameterization of processes within the spin-up period.

A model that equilibrates to a soil carbon store well outside the observed range should be examined with care. A very large amount of stored carbon increases the potential for the land surface to become a source as even a tiny relative change in decay rate can strongly enhance $R_{\mathrm{h}}$ and possibly reach a tipping point where it offsets increases in $\mathrm{SOC}_{\mathrm{in}}$. Conversely, a very small SOC store increases the likelihood that it will remain a sink. Such results are likely to be artefacts of model implementation when SOC values are largely inconsistent with observed ranges.

In conclusion, we recommend that future intercomparisons should constrain model parameters so that each model achieves an equilibrated state similar to observations as the 
outcome of the spin-up procedure. This would remove a degree of freedom associated with the process linking initialization to equilibration via a poorly constrained spin-up procedure when comparing differences in projected changes.

Acknowledgements. This work was supported by the Australian Research Council through grants DP110102618 and CE110001028. We thank P. Petrelli for the availability of CMIP5 data and the National Computational Infrastructure for data hosting and computational resources to process these model data. We thank $\mathrm{K}$. Todd-Brown for guidance in processing the HWSD database and Y. Zhang for information about the BCC-CSM1.1 model.

We acknowledge the World Climate Research Programme's Working Group on Coupled Modelling, which is responsible for CMIP, and we thank the climate modelling groups (listed in Table 1 of this paper) for producing and making available their model output. For CMIP the US Department of Energy's Program for Climate Model Diagnosis and Intercomparison provides coordinating support and led development of software infrastructure in partnership with the Global Organization for Earth System Science Portals.

Edited by: C. Sierra

\section{References}

Ahlström, A., Smith, B., Lindström, J., Rummukainen, M., and Uvo, C. B.: GCM characteristics explain the majority of uncertainty in projected 21st century terrestrial ecosystem carbon balance, Biogeosciences, 10, 1517-1528, doi:10.5194/bg-10-15172013, 2013.

Allison, S. D., Wallenstein, M. D., and Bradford, M. A.: Soil-carbon response to warming dependent on microbial physiology, Nat. Geosci., 3, 336-340, doi:10.1038/ngeo846, 2010.

Anav, A., Friedlingstein, P., Kidston, M., Bopp, L., Ciais, P., Cox, P., Jones, C., Jung, M., Myneni, R., and Zhu, Z.: Evaluating the Land and Ocean Components of the Global Carbon Cycle in the CMIP5 Earth System Models, J. Clim., 26, 6801-6843, doi:10.1175/JCLI-D-12-00417.1, 2013.

Arora, V. K. and Boer, G. J.: Uncertainties in the 20th century carbon budget associated with land use change, Glob. Chang. Biol., 16, 3327-3348, doi:10.1111/j.1365-2486.2010.02202.x, 2010.

Bentsen, M., Bethke, I., Debernard, J. B., Iversen, T., Kirkevåg, A., Seland, Ø., Drange, H., Roelandt, C., Seierstad, I. A., Hoose, C., and Kristjánsson, J. E.: The Norwegian Earth System Model, NorESM1-M - Part 1: Description and basic evaluation of the physical climate, Geosci. Model Dev., 6, 687-720, doi:10.5194/gmd-6-687-2013, 2013.

Bishop, C. H. and Abramowitz, G.: Climate model dependence and the replicate Earth paradigm, Clim. Dynam., 41, 885-900, doi:10.1007/s00382-012-1610-y, 2012.

Canadell, J. G., Le Quéré, C., Raupach, M. R., Field, C. B., Buitenhuis, E. T., Ciais, P., Conway, T. J., Gillett, N. P., Houghton, R. A., and Marland, G.: Contributions to accelerating atmospheric $\mathrm{CO}_{2}$ growth from economic activity, carbon intensity, and efficiency of natural sinks, P. Natl. Acad. Sci. USA, 104, 18866-18870, doi:10.1073/pnas.0702737104, 2007.

Chylek, P., Li, J., Dubey, M. K., Wang, M., and Lesins, G.: Observed and model simulated 20th century Arctic temperature variability: Canadian Earth System Model CanESM2, Atmos. Chem. Phys. Discuss., 11, 22893-22907, doi:10.5194/acpd-1122893-2011, 2011.

Clark, D. B., Mercado, L. M., Sitch, S., Jones, C. D., Gedney, N., Best, M. J., Pryor, M., Rooney, G. G., Essery, R. L. H., Blyth, E., Boucher, O., Harding, R. J., Huntingford, C., and Cox, P. M.: The Joint UK Land Environment Simulator (JULES), model description - Part 2: Carbon fluxes and vegetation dynamics, Geosci. Model Dev., 4, 701-722, doi:10.5194/gmd-4-701-2011, 2011.

Collins, W. J., Bellouin, N., Doutriaux-Boucher, M., Gedney, N., Halloran, P., Hinton, T., Hughes, J., Jones, C. D., Joshi, M., Liddicoat, S., Martin, G., O’Connor, F., Rae, J., Senior, C., Sitch, S., Totterdell, I., Wiltshire, A., and Woodward, S.: Development and evaluation of an Earth-System model - HadGEM2, Geosci. Model Dev., 4, 1051-1075, doi:10.5194/gmd-4-10512011, 2011.

Cox, P. M.: Description of the TRIFFID dynamic global vegetation model, Met Office Hadley Centre Tech. Note, 24, 17 pp., 2001.

Davidson, E. A. and Janssens, I. A.: Temperature sensitivity of soil carbon decomposition and feedbacks to climate change, Nature, 440, 165-173, doi:10.1038/nature04514, 2006.

Doney, S. C., Lindsay, K., Fung, I., and John, J.: Natural Variability in a Stable, 1000-Yr Global Coupled Climate-Carbon Cycle Simulation, J. Climate, 19, 3033-3054, doi:10.1175/JCLI3783.1, 2006.

Dufresne, J.-L., Foujols, M.-A., Denvil, S., Caubel, A., Marti, O., Aumont, O., Balkanski, Y., Bekki, S., Bellenger, H., Benshila, R., Bony, S., Bopp, L., Braconnot, P., Brockmann, P., Cadule, P., Cheruy, F., Codron, F., Cozic, A., Cugnet, D., Noblet, N., Duvel, J.-P., Ethé, C., Fairhead, L., Fichefet, T., Flavoni, S., Friedlingstein, P., Grandpeix, J.-Y., Guez, L., Guilyardi, E., Hauglustaine, D., Hourdin, F., Idelkadi, A., Ghattas, J., Joussaume, S., Kageyama, M., Krinner, G., Labetoulle, S., Lahellec, A., Lefebvre, M.-P., Lefevre, F., Levy, C., Li, Z. X., Lloyd, J., Lott, F., Madec, G., Mancip, M., Marchand, M., Masson, S., Meurdesoif, Y., Mignot, J., Musat, I., Parouty, S., Polcher, J., Rio, C., Schulz, M., Swingedouw, D., Szopa, S., Talandier, C., Terray, P., Viovy, N., and Vuichard, N.: Climate change projections using the IPSL-CM5 Earth System Model: from CMIP3 to CMIP5, Clim. Dynam., 40, 2123-2165, doi:10.1007/s00382-012-1636-1, 2013.

Dunne, J. P., John, J. G., Adcroft, A. J., Griffies, S. M., Hallberg, R. W., Shevliakova, E., Stouffer, R. J., Cooke, W., Dunne, K. A., Harrison, M. J., Krasting, J. P., Malyshev, S. L., Milly, P. C. D., Phillipps, P. J., Sentman, L. T., Samuels, B. L., Spelman, M. J., Winton, M., Wittenberg, A. T., and Zadeh, N.: GFDL's ESM2 Global Coupled Climate-Carbon Earth System Models. Part I: Physical Formulation and Baseline Simulation Characteristics, J. Climate, 25, 6646-6665, doi:10.1175/JCLI-D-11-00560.1, 2012.

Exbrayat, J.-F., Pitman, A. J., Abramowitz, G., and Wang, Y.-P.: Sensitivity of net ecosystem exchange and heterotrophic respiration to parameterization uncertainty, J. Geophys. Res.-Atmos., 118, 1640-1651, doi:10.1029/2012JD018122, $2013 \mathrm{a}$.

Exbrayat, J.-F., Pitman, A. J., Zhang, Q., Abramowitz, G., and Wang, Y.-P.: Examining soil carbon uncertainty in a global model: response of microbial decomposition to temperature, moisture and nutrient limitation, Biogeosciences, 10, 7095-7108, doi:10.5194/bg-10-7095-2013, 2013 b. 
Exbrayat, J.-F., Pitman, A. J., and Abramowitz, G.: Disentangling residence time and temperature sensitivity of microbial decomposition in a global soil carbon model, Biogeosciences Discuss., 11, 4995-5021, doi:10.5194/bgd-11-4995-2014, 2014.

Falloon, P., Jones, C. D., Ades, M., and Paul, K.: Direct soil moisture controls of future global soil carbon changes: An important source of uncertainty, Global Biogeochem. Cy., 25, GB3010, doi:10.1029/2010GB003938, 2011.

FAO/IIASA/ISRIC/ISSCAS/JRC: Harmonized World Soil Database (version 1.21). FAO, Rome, Italy and IIASA, Laxenburg, Austria, 2012.

Foley, J. A.: An equilibrium model of the terrestrial carbon budget, Tellus B, 47, 310-319, doi:10.1034/j.1600-0889.47.issue3.3.x, 1995.

Friedlingstein, P., Meinshausen, M., Arora, V. K., Jones, C. D., Anav, A., Liddicoat, S. K., and Knutti, R.: Uncertainties in CMIP5 Climate Projections due to Carbon Cycle Feedbacks, J. Climate, 27, 511-526, doi:10.1175/JCLI-D-12-00579.1, 2014.

Friend, A. D., Lucht, W., Rademacher, T. T., Keribin, R., Betts, R., Cadule, P., Ciais, P., Clark, D. B., Dankers, R., Falloon, P. D., Ito, A., Kahana, R., Kleidon, A., Lomas, M. R., Nishina, K., Ostberg, S., Pavlick, S., Peylin, P., Schaphoff, S., Vuichard, N., Warszawski, L., Wiltshire, A., and Woodward, F. I.: Carbon residence time dominates uncertainty in terrestrial vegetation 508 responses to future climate and atmospheric $\mathrm{CO}_{2}, \mathrm{P}$. Natl. Acad. Sci., 111, 3280-3285, doi:10.1073/pnas.1222477110, 2014.

Gent, P. R., Danabasoglu, G., Donner, L. J., Holland, M. M., Hunke, E. C., Jayne, S. R., Lawrence, D. M., Neale, R. B., Rasch, P. J., Vertenstein, M., Worley, P. H., Yang, Z.-L., and Zhang, M.: The Community Climate System Model Version 4, J. Climate, 24, 4973-4991, doi:10.1175/2011JCLI4083.1, 2011.

Giorgetta, M. A., Jungclaus, J., Reick, C. H., Legutke, S., Bader, J., Böttinger, M., Brovkin, V., Crueger, T., Esch, M., Fieg, K., Glushak, K., Gayler, V., Haak, H., Hollweg, H.-D., Ilyina, T., Kinne, S., Kornblueh, L., Matei, D., Mauritsen, T., Mikolajewicz, U., Mueller, W., Notz, D., Pithan, F., Raddatz, T., Rast, S., Redler, R., Roeckner, E., Schmidt, H., Schnur, R., Segschneider, J., Six, K. D., Stockhause, M., Timmreck, C., Wegner, J., Widmann, H., Wieners, K.-H., Claussen, M., Marotzke, J., and Stevens, B.: Climate and carbon cycle changes from 1850 to 2100 in MPI-ESM simulations for the Coupled Model Intercomparison Project phase 5, J. Adv. Model. Earth Syst., 5, 572-597, doi:10.1002/jame.20038, 2013.

Hugelius, G., Tarnocai, C., Broll, G., Canadell, J. G., Kuhry, P., and Swanson, D. K.: The Northern Circumpolar Soil Carbon Database: spatially distributed datasets of soil coverage and soil carbon storage in the northern permafrost regions, Earth Syst. Sci. Data, 5, 3-13, doi:10.5194/essd-5-3-2013, 2013.

Ito, A.: A historical meta-analysis of global terrestrial net primary productivity: are estimates converging?, Glob. Change Biol., 17, 3161-3175, doi:10.1111/j.1365-2486.2011.02450.x, 2011.

Jenkinson, D. S.: The turnover of organic-carbon and nitrogen in soil, Philos. T. Roy. Soc. London, 329, 361-368, 1990.

Ji, J., Huang, M., and Li, K.: Prediction of carbon exchanges between China terrestrial ecosystem and atmosphere in 21 st century, Sci. China Ser. D, 51, 885-898, doi:10.1007/s11430-0080039-y, 2008.

Jobbágy, E. G. and Jackson, R. B.: The vertical distribution of soil organic carbon and its relation to climate and vegetation, Ecol. Appl., 10, 423-436, doi:10.1890/10510761(2000)010[0423:TVDOSO]2.0.CO;2, 2000

Kirschbaum, M. U. F.: Soil respiration under prolonged soil warming: are rate reductions caused by acclimation or substrate loss?, Glob. Chang. Biol., 10, 1870-1877, doi:10.1111/j.13652486.2004.00852.x, 2004.

Knorr, W.: Annual and interannual $\mathrm{CO}_{2}$ exchanges of the terrestrial biosphere: process-based simulations and uncertainties, Glob. Ecol. Biogeogr., 9, 225-252, doi:10.1046/j.13652699.2000.00159.x, 2000.

Knorr, W., Prentice, I. C., House, J. I., and Holland, E. A.: Longterm sensitivity of soil carbon turnover to warming, Nature, 433 , 298-301, doi:10.1038/nature03226, 2005.

Knutti, R. and Sedlácěk, J.: Robustness and uncertainties in the new CMIP5 climate model projections, Nat. Clim. Change, 3 , 369-373, doi:10.1038/nclimate1716, 2013.

Krinner, G., Viovy, N., de Noblet-Ducoudré, N., Ogée, J., Polcher, J., Friedlingstein, P., Ciais, P., Sitch, S., and Prentice, I. C.: A dynamic global vegetation model for studies of the coupled atmosphere-biosphere system, Global Biogeochem. Cy., 19, GB1015, doi:10.1029/2003GB002199, 2005.

Lawrence, D. M., Oleson, K. W., Flanner, M. G., Thornton, P. E., Swenson, S. C., Lawrence, P. J., Zeng, X., Yang, Z.-L., Levis, S., Sakaguchi, K., Bonan, G. B., and Slater, A. G.: Parameterization improvements and functional and structural advances in Version 4 of the Community Land Model, J. Adv. Model. Earth Syst., 3, M03001, doi:10.1029/2011MS000045, 2011.

Le Quéré, C., Raupach, M. R., Canadell, J. G., Marland, G., Bopp, L., Ciais, P., Conway, T. J., Doney, S. C., Feely, R. A., Foster, P., Friedlingstein, P., Gurney, K., Houghton, R. A., House, J. I., Huntingford, C., Levy, P. E., Lomas, M. R., Majkut, J., Metzl, N., Ometto, J. P., Peters, G. P., Prentice, I. C., Randerson, J. T., Running, S. W., Sarmiento, J. L., Schuster, U., Sitch, S., Takahashi, T., Viovy, N., van der Werf, G. R., and Woodward, F. I.: Trends in the sources and sinks of carbon dioxide, Nat. Geosci., 2, 831-836, doi:10.1038/ngeo689, 2009.

Lloyd, J. and Taylor, J. A.: On the Temperature Dependence of Soil Respiration, Funct. Ecol., 8, 315-323, 1994.

Lund, M., Lafleur, P. M., Roulet, N. T., Lindroth, A., Christensen, T. R., Aurela, M., Chojnicki, B. H., Flanagan, L. B., Humphreys, E. R., Laurila, T., Oechel, W. C., Olejnik, J., Rinne, J., Schubert, P., and Nilsson, M. B.: Variability in exchange of $\mathrm{CO}_{2}$ across 12 northern peatland and tundra sites, Glob. Chang. Biol., 16, 2436-2448, doi:10.1111/j.1365-2486.2009.02104.x, 2010.

Luo, Y., Wan, S., Hui, D., and Wallace, L. L.: Acclimatization of soil respiration to warming in a tall grass prairie, Nature, 413, 622-625, doi:10.1038/35098065, 2001.

Nishina, K., Ito, A., Beerling, D. J., Cadule, P., Ciais, P., Clark, D. B., Falloon, P., Friend, A. D., Kahana, R., Kato, E., Keribin, R., Lucht, W., Lomas, M., Rademacher, T. T., Pavlick, R., Schaphoff, S., Vuichard, N., Warszawaski, L., and Yokohata, T.: Quantifying uncertainties in soil carbon responses to changes in global mean temperature and precipitation, Earth Syst. Dynam., 5, 197-209, doi:10.5194/esd-5-197-2014, 2014.

Parton, W. J., Schimel, D. S., Cole, C. V., and Ojima, D. S.: Analysis of Factors Controlling Soil Organic Matter Levels in Great Plains Grasslands, Soil Sci. Soc. Am. J., 51, 1173-1179, doi:10.2136/sssaj1987.03615995005100050015x, 1987. 
Parton, W. J., Stewart, J. W. B., and Cole, C. V.: Dynamics of C, N, P and $\mathrm{S}$ in grassland soils: a model, Biogeochemistry, 5, 109-131, doi:10.1007/BF02180320, 1988.

Raddatz, T. J., Reick, C. H., Knorr, W., Kattge, J., Roeckner, E., Schnur, R., Schnitzler, K.-G., Wetzel, P., and Jungclaus, J.: Will the tropical land biosphere dominate the climate-carbon cycle feedback during the twenty-first century?, Clim. Dynam., 29, 565-574, doi:10.1007/s00382-007-0247-8, 2007.

Randerson, J. T., Thompson, M. V., Conway, T. J., Fung, I. Y., and Field, C. B.: The contribution of terrestrial sources and sinks to trends in the seasonal cycle of atmospheric carbon dioxide, Global Biogeochem. Cy., 11, 535-560, doi:10.1029/97GB02268, 1997.

Sato, H., Itoh, A., and Kohyama, T.: SEIB-DGVM: A new Dynamic Global Vegetation Model using a spatially explicit individual-based approach, Ecol. Model., 200, 279-307, doi:10.1016/j.ecolmodel.2006.09.006, 2007.

Schmidt, M. W. I., Torn, M. S., Abiven, S., Dittmar, T., Guggenberger, G., Janssens, I. A., Kleber, M., Kögel-Knabner, I., Lehmann, J., Manning, D. A. C., Nannipieri, P., Rasse, D. P., Weiner, S., and Trumbore, S. E.: Persistence of soil organic matter as an ecosystem property, Nature, 478, 49-56, doi:10.1038/nature10386, 2011.

Shangguan, W., Dai, Y., Duan, Q., Liu, B., and Yuan, H.: A global soil data set for earth system modeling, J. Adv. Model. Earth Syst., 6, 249-263, doi:10.1002/2013MS000293, 2014.

Shevliakova, E., Pacala, S. W., Malyshev, S., Hurtt, G. C., Milly, P. C. D., Caspersen, J. P., Sentman, L. T., Fisk, J. P., Wirth, C., and Crevoisier, C.: Carbon cycling under 300 years of land use change: Importance of the secondary vegetation sink, Global Biogeochem. Cy., 23, GB2022, doi:10.1029/2007GB003176, 2009.

Shindell, D. T., Pechony, O., Voulgarakis, A., Faluvegi, G., Nazarenko, L., Lamarque, J.-F., Bowman, K., Milly, G., Kovari, B., Ruedy, R., and Schmidt, G. A.: Interactive ozone and methane chemistry in GISS-E2 historical and future climate simulations, Atmos. Chem. Phys., 13, 2653-2689, doi:10.5194/acp-13-26532013, 2013.

Taylor, K. E., Stouffer, R. J., and Meehl, G. A.: An overview of CMIP5 and the experiment design, B. Am. Meteorol. Soc., 93, 485-498, doi:10.1175/BAMS-D-11-00094.1, 2012.

Thornton, P. E. and Rosenbloom, N. A.: Ecosystem model spinup: Estimating steady state conditions in a coupled terrestrial carbon and nitrogen cycle model, Ecol. Model., 189, 25-48, doi:10.1016/j.ecolmodel.2005.04.008, 2005.

Thornton, P. E., Lamarque, J.-F., Rosenbloom, N. A., and Mahowald, N. M.: Influence of carbon-nitrogen cycle coupling on land model response to $\mathrm{CO}_{2}$ fertilization and climate variability, Global Biogeochem. Cy., 21, GB4018, doi:10.1029/2006GB002868, 2007.
Todd-Brown, K. E. O., Randerson, J. T., Post, W. M., Hoffman, F. M., Tarnocai, C., Schuur, E. A. G., and Allison, S. D.: Causes of variation in soil carbon simulations from CMIP5 Earth system models and comparison with observations, Biogeosciences, 10, 1717-1736, doi:10.5194/bg-10-1717-2013, 2013.

Todd-Brown, K. E. O., Randerson, J. T., Hopkins, F., Arora, V., Hajima, T., Jones, C., Shevliakova, E., Tjiputra, J., Volodin, E., Wu, T., Zhang, Q., and Allison, S. D.: Changes in soil organic carbon storage predicted by Earth system models during the 21 st century, Biogeosciences, 11, 2341-2356, doi:10.5194/bg-11-23412014, 2014.

Warszawski, L., Frieler, K., Huber, V., Piontek, F., Serdeczny, O., and Schewe, J.: The Inter-Sectoral Impact Model Intercomparison Project (ISI-MIP): project framework, P. Natl. Acad. Sci. USA, 111, 3228-3232, doi:10.1073/pnas.1312330110, 2014.

Watanabe, S., Hajima, T., Sudo, K., Nagashima, T., Takemura, T., Okajima, H., Nozawa, T., Kawase, H., Abe, M., Yokohata, T., Ise, T., Sato, H., Kato, E., Takata, K., Emori, S., and Kawamiya, M.: MIROC-ESM 2010: model description and basic results of CMIP5-20c3m experiments, Geosci. Model Dev., 4, 845-872, doi:10.5194/gmd-4-845-2011, 2011.

Wieder, W. R., Bonan, G. B., and Allison, S. D.: Global soil carbon projections are improved by modelling microbial processes, Nature Climate Change, 3, 909-912, doi:10.1038/nclimate1951, 2013.

Wu, T., Li, W., Ji, J., Xin, X., Li, L., Wang, Z., Zhang, Y., Li, J., Zhang, F., Wei, M., Shi, X., Wu, F., Zhang, L., Chu, M., Jie, W., Liu, Y., Wang, F., Liu, X., Li, Q., Dong, M., Liang, X., Gao, Y., and Zhang, J.: Global carbon budgets simulated by the Beijing Climate Center Climate System Model for the last century, J. Geophys. Res.-Atmos., 118, 4326-4347, doi:10.1002/jgrd.50320, 2013.

Xenakis, G. and Williams, M.: Comparing microbial and chemical kinetics for modelling soil organic carbon decomposition using the DecoChem v1.0 and DecoBio v1.0 models, Geosci. Model Dev., 7, 1519-1533, doi:10.5194/gmd-7-1519-2014, 2014.

Xia, J., Luo, Y., Wang, Y.-P., and Hararuk, O.: Traceable components of terrestrial carbon storage capacity in biogeochemical models, Glob. Change Biol., 19, 2104-16, doi:10.1111/gcb.12172, 2013.

Xia, J. Y., Luo, Y. Q., Wang, Y.-P., Weng, E. S., and Hararuk, O.: A semi-analytical solution to accelerate spin-up of a coupled carbon and nitrogen land model to steady state, Geosci. Model Dev., 5, 1259-1271, doi:10.5194/gmd-5-1259-2012, 2012. 